Scientia Marina 71(2)

June 2007, 287-292, Barcelona (Spain)

ISSN: 0214-8358

\title{
Decapod crustaceans associated with the snakelock anemone Anemonia sulcata. Living there or just passing by?
}

\author{
RICARDO CALADO, GISELA DIONÍSIO and MARIA TERESA DINIS \\ CCMAR Universidade do Algarve, Campus de Gambelas, 8000-117 Faro, Portugal. E-mail: rjcalado@hotmail.com
}

\begin{abstract}
SUMMARY: The present work identifies the decapod crustaceans that associate with Anemonia sulcata on the southwestern Atlantic coast of Portugal and characterises their host use pattern. It determines whether the anemone is monopolised by any species, resulting in the exclusion of conspecifics or other decapods and, under laboratory conditions, it evaluates the degree of association between each species and A. sulcata. From all sampled anemones, $79 \%$ harboured at least 1 decapod crustacean, with the majority displaying either one or two specimens (32 and $24 \%$, respectively). The most abundant species were the shrimp Periclimenes sagittifer and the crab Inachus phalangium (representing 36 and $31 \%$ of collected specimens, respectively), which displayed lasting associations and were commonly recorded among the tentacles of the host. The species Eualus occultus, E. complex cranchii, Clibanarius erythropus, Maja brachydactyla, Pilumnus hirtellus and Polybius (Necora) puber displayed short-term associations, were mainly present on the substratum near the base, and avoided the tentacles of A. sulcata. Periclimenes sagittifer and I. phalangium were only recorded alone or in heterosexual pairs, appearing to efficiently defend their host against conspecifics. The majority of recorded species only seem to temporarily associate with A. sulcata, in order to seek protection from predators when other shelters are unavailable.
\end{abstract}

Keywords: Anemonia sulcata, associative behaviour, decapod crustaceans.

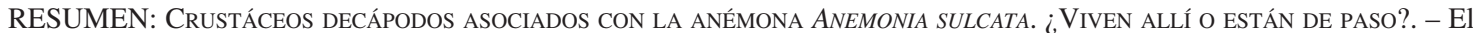
presente trabajo identifica los crustáceos decápodos que viven asociados a la anémona Anemonia sulcata en la costa atlántica sudoccidental de Portugal y caracteriza las pautas de utilización de la especie hospedadora. Verifica si la anémona es monopolizada por alguna especie, resultando en la exclusión de conespecíficos u otros decápodos, y evalúa en condiciones de laboratorio el grado de asociación entre cada especie y A. sulcata. A partir de todas las anémonas muestreadas, el 79\% hospedó como mínimo una especie de crustáceo decápodo, la mayor parte de ellas con uno o dos individuos $(32$ y $24 \%$ respectivamente). Las especies más abundantes fueron el camarón carideo Periclimenes sagittifer y el cangrejo Inachus phalangium (representando respectivamente el $36 \%$ y $31 \%$ de los individuos recolectados). Estas especies mostraron asociaciones duraderas y fueron muestreadas comunmente entre los tentáculos del huesped. Las especies Eualus occultus, E. complejo cranchii, Clibanarius erythropus, Maja brachydactyla, Pilumnus hirtellus y Polybius (Necora) puber mostraron asociaciones no duraderas, y estuvieron principalmente presentes sobre el sustrato cerca de la base de la anémona, evitando los tentáculos. Periclimenes sagittifer e I. phalangium solamente se hallaron sólos o en pares heterosexuales, y mostraron defender eficientemente su huésped contra conespecíficos. La mayoría de especies halladas sólo parecen asociarse temporalmente con A. sulcata para buscar protección contra predadores cuando otros refugios no están disponibles.

Palabras clave: Anemonia sulcata, comportamiento asociativo, crustáceos decápodos.

\section{INTRODUCTION}

The symbiotic life style is one of the greatest environmental adaptations of marine crustaceans (Ross, 1983). Although most symbiotic decapods inhabit their host as solitary individuals or as a mated pair (Knowlton, 1980; Haines et al., 1994; Omori et al., 1994; Palmer, 1995), there are also records of the occurrence of aggregations of individuals in a single host (Nizinski, 1989; Baeza and 
Thiel, 2000). Associations between sea anemones and decapods are not unusual and have already been reported from tropical and temperate areas in intertidal and subtidal regimes (Wirtz, 1997; Jonsson et al., 2001; Thiel and Baeza, 2001; Khan et al., 2004). Decapods associating with sea anemones may seek protection, food, a reproductive mate or all of these features (Wirtz and Diesel, 1983; Fautin et al., 1995; Baeza and Thiel, 2003; Valdivia and Stotz, 2006).

In the coastal areas of the northeastern Atlantic, the snakelock anemone Anemonia sulcata (Pennant, 1717) is a well known host of the shrimp Periclimenes sagittifer (Norman, 1861) and the crab Inachus phalangium (J.C. Fabricius, 1775) (Wirtz and Diesel, 1983; Grippa and Udekem d'Acoz, 1996). Occasionally, other decapod species have also been recorded associated with $A$. sulcata, but to our knowledge a detailed study on this subject has never been performed.

The present work examines the decapod crustaceans that associate with A. sulcata on the southwestern Atlantic coast of Portugal, and evaluates their degree of association under laboratory conditions. For the decapod species that associate with A. sulcata, it determines whether all species occupy similar areas of the host and whether any decapod species monopolise the sea anemone and exclude conspecifics or other decapod species.

\section{MATERIALS AND METHODS}

\section{Field study}

Decapod crustaceans associated with Anemonia sulcata were collected with the help of hand nets and transparent plastic bottles in July 2005 in 100 similar-sized individual anemones (tentacle span between 120 and $140 \mathrm{~mm}$ ), with the number and specific position of each specimen on the anemone being recorded. All sampled anemones were randomly selected in the area of Sagres (southwestern Atlantic coast of Portugal) and were inspected during the day time using SCUBA gear at depths of 6-8 $\mathrm{m}$ in a sheltered bay. Twenty specimens of A. sulcata and of each decapod species recorded in association with the anemone were collected and transported to the laboratory for experiments studying decapodanemone association.

\section{Laboratory experiments on decapod-anemone association}

Individuals of decapod species recorded in association with A. sulcata and individual anemones were stored in 10 glass aquaria (54 1) connected in parallel to a recirculation system composed of a 270 1 sump equipped with a wet-dry filter with bioballs (assuring biological filtration), a protein skimmer and one $55 \mathrm{~W}$ ultra-violet steriliser.

To test the degree of association between the collected decapod species and A. sulcata the bottom surface of a glass aquarium $(0.60 \mathrm{~m}$ long $\mathrm{x} 0.20 \mathrm{~m}$ wide x $0.20 \mathrm{~m}$ high, total volume 241 ) was divided into three equal areas ( $0.20 \mathrm{~m}$ long $\mathrm{x} 0.20 \mathrm{~m}$ wide): a central empty area, an anemone area and a rock area. The rock placed in the rock area had a similar volume to the anemone placed in the anemone area. Each decapod collected from the field was placed in the central empty area and allowed to freely choose the rock or the anemone area for shelter. Each trial lasted 5 minutes, with the aquarium water being fully replaced between trials using different specimens. The anemone used in trials with different specimens was randomly selected from the pool of 20 A. sulcata collected from the field.

\section{Statistical analyses}

Location of decapod crustaceans present on $A$. sulcata and laboratory results of the decapodanemone association experiments were analysed using the chi-square test, the null prediction being a random distribution of decapods over the anemone areas (mouth, tentacles, column and substrate near the base) and the three areas of the experimental aquarium (central empty area, anemone area and rock area) (Zar, 1996).

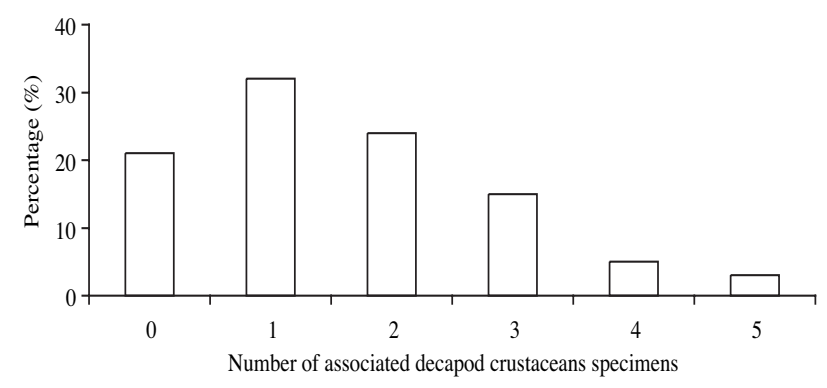

FIG. 1. - Percentage of sea anemones Anemonia sulcata displaying associated decapod crustaceans $(\mathrm{n}=100)$. 
TABLE 1. - Species composition (\%) and total number of specimens from each decapod crustacean species recorded associated with Anemonia sulcata.

\begin{tabular}{lcc}
\hline & Species composition & N. of specimens \\
\hline Periclimenes sagittifer & $36.3 \%$ & 58 \\
Inachus phalangium & $31.0 \%$ & 49 \\
Polybius (Necora) puber & $8.8 \%$ & 14 \\
Eualus occultus & $10.0 \%$ & 16 \\
Eualus cranchii & $7.5 \%$ & 12 \\
Clibanarius erythropus & $4.4 \%$ & 7 \\
Maja brachydactyla & $1.3 \%$ & 2 \\
Pilumnus hirtellus & $1.3 \%$ & 2 \\
\hline
\end{tabular}

\section{RESULTS}

From the 100 sampled A. sulcata, 79\% harboured at least one decapod crustacean. The majority of sampled snakelock anemones displayed either one or two decapods (32 and 24\%, respectively) (Fig. 1).

The following decapod species were recorded associated with A. sulcata: the shrimps Periclimenes sagittifer, Eualus occultus (Lebour, 1936), Eualus complex cranchii (Leach, 1817), the hermit crab Clibanarius erythropus (Latreille, 1818) and the crabs Inachus phalangium, Maja brachydactyla Balss, 1922, Pilumnus hirtellus (Linnaeus, 1761) and Polybius (Necora) puber (Linnaeus, 1767), for a total of 160 specimens. All M. brachydactyla and $P$. (N.) puber specimens recorded in the present study were juveniles. The most abundant species collected
TABLE 2. - Group size frequency (\%) of decapod species recorded on Anemonia sulcata ( $\mathrm{n}=$ number of groups recorded, * always present as a mated pair); s: specimen/s.

\begin{tabular}{lccc}
\hline & \multicolumn{3}{c}{ Group size } \\
& $1 \mathrm{~s}$ & $2 \mathrm{~s}$ & 3 or $+\mathrm{s}$ \\
\hline & & & \\
\hline & & & \\
Periclimenes sagittifer $(\mathrm{n}=43)$ & $65.1 \%$ & $34.9 \% *$ & $0.0 \%$ \\
Inachus phalangium $(\mathrm{n}=37)$ & $67.6 \%$ & $62.4 \% *$ & $0.0 \%$ \\
Polybius $($ Necora $)$ puber $(\mathrm{n}=14)$ & $100.0 \%$ & $0.0 \%$ & $0.0 \%$ \\
Eualus occultus $(\mathrm{n}=12)$ & $75.0 \%$ & $16.7 \%$ & $8.3 \%$ \\
Eualus cranchii $(\mathrm{n}=10)$ & $80.0 \%$ & $20.0 \%$ & $0.0 \%$ \\
Clibanarius erythropus $(\mathrm{n}=3)$ & $66.6 \%$ & $0.0 \%$ & $33.4 \%$ \\
Maja brachydactyla $(\mathrm{n}=2)$ & $100.0 \%$ & $0.0 \%$ & $0.0 \%$ \\
Pilumnus hirtellus $(\mathrm{n}=2)$ & $100.0 \%$ & $0.0 \%$ & $0.0 \%$ \\
& & & \\
\hline
\end{tabular}

were the shrimp P. sagittifer and the crab I. phalangium, accounting for 36 and $31 \%$ of all collected specimens, respectively (Table 1 ). Whenever two $P$. sagittifer or two I. phalangium specimens were present on a single A. sulcata (in 15 and $12 \%$ of sampled sea anemones, respectively), these always formed a mated pair, with no observation ever recording two conspecifics of the same sex on the same host. The maximum number of conspecifics recorded on a single host was 5 for the hermit crab C. erythropus (Table 2).

The location of decapod crustaceans associated with A. sulcata is summarised in Table 3. Although $M$. brachydactyla and P. hirtellus were always in the substrate near the base of A. sulcata, their location was not analysed due to the reduced

TABLE 3. - Location of decapod specimens associated with Anemonia sulcata (excluding Maja brachydactyla and Pilumnus hirtellus) ( $\mathrm{n}=$ number of specimens recorded).

\begin{tabular}{|c|c|c|c|c|c|c|}
\hline & \multicolumn{3}{|c|}{ Anemone zones } & \multirow[b]{2}{*}{ Substratum (near base) } & \multirow[b]{2}{*}{$\chi^{2}$} & \multirow[b]{2}{*}{$P$ value } \\
\hline & Mouth & Tentacles & Column & & & \\
\hline Periclimenes sagittifer $(\mathrm{n}=58)$ & 0 & 35 & 21 & 2 & 57.17 & $P<0.0001$ \\
\hline Inachus phalangium $(\mathrm{n}=49)$ & 0 & 31 & 15 & 3 & 48.55 & $P<0.0001$ \\
\hline Eualus occultus $(\mathrm{n}=16)$ & 0 & 0 & 6 & 10 & 18.00 & $P=0.0004$ \\
\hline Polybius (Necora) puber $(\mathrm{n}=14)$ & 0 & 0 & 0 & 14 & 42.00 & $P<0.0001$ \\
\hline Eualus cranchii $(\mathrm{n}=12)$ & 0 & 0 & 4 & 8 & 14.67 & $P=0.0021$ \\
\hline Clibanarius erythropus $(\mathrm{n}=7)$ & 0 & 0 & 0 & 7 & 21.00 & $P=0.0001$ \\
\hline
\end{tabular}

TABLE 4. - Shelter selection of decapod species associated with Anemonia sulcata under laboratory conditions $(\mathrm{n}=20$ observations per species).

\begin{tabular}{|c|c|c|c|c|c|}
\hline & Rock & $\begin{array}{l}\text { Aquarium areas } \\
\text { Central (empty) }\end{array}$ & Anemone & $\chi^{2}$ & $P$ value \\
\hline Periclimenes sagittifer & $5 \%$ & $0 \%$ & $95 \%$ & 34.30 & $P<0.0001$ \\
\hline Eualus occultus & $75 \%$ & $20 \%$ & $5 \%$ & 16.30 & $P<0.0001$ \\
\hline Eualus cranchii & $85 \%$ & $5 \%$ & $10 \%$ & 24.10 & $P<0.0001$ \\
\hline Clibanarius erythropus & $85 \%$ & $10 \%$ & $5 \%$ & 24.10 & $P<0.0001$ \\
\hline Inachus phalangium & $10 \%$ & $0 \%$ & $90 \%$ & 29.20 & $P<0.0001$ \\
\hline Maja brachydactyla & $95 \%$ & $5 \%$ & $0 \%$ & 34.30 & $P<0.0001$ \\
\hline Pilumnus hirtellus & $85 \%$ & $10 \%$ & $5 \%$ & 24.10 & $P<0.0001$ \\
\hline Polybius (Necora) puber & $55 \%$ & $20 \%$ & $25 \%$ & 4.30 & $P=0.1165$ \\
\hline
\end{tabular}


number of recorded specimens $(\mathrm{n}=2$ for each species). The chi-square test revealed that a significantly higher proportion of $P$. sagittifer and $I$. phalangium $(P<0.0001)$ were recorded among the tentacles of A. sulcata than in other areas. All other recorded species were preferentially located in the substrate near the base of the anemone. No species was ever recorded in the area around the mouth of the host anemone.

Laboratory results of decapod-anemone association experiments revealed that when able to choose between a rock, an empty area or a snakelock anemone, a significantly higher $(\mathrm{P}<0.0001)$ number of $P$. sagittifer and I. phalangium chose $A$. sulcata for shelter (Table 4). With the exception of $P$. (N.) puber, which randomly occupied any of the three aquarium areas, all other recorded species associated in the field with A. sulcata preferentially $(\mathrm{P}<0.0001)$ sought shelter in the rock area, under laboratory conditions.

\section{DISCUSSION}

The large number of snakelock anemones recorded in the present work that hosted several decapod species seems to indicate that this type of association is not uncommon, at least in the study area. The percentage of A. sulcata that harboured at least one associated crustacean (79\%) was similar to that recorded for the anemones Lebrunia danae (Duchassaing and Michelotti, 1860) (75\%), Bartholomea annulata (Le Sueur, 1860) (84\%) and Telmatactis cricoides (Duchassaing, 1850) (86\%) (Herrnkind et al., 1976; Wirtz, 1997).

The large groups of decapods from one species known to cohabit on a single host individual (e.g. up to 18 Thor amboinensis (De Man, 1888) associated with T. cricoides (Wirtz, 1997) and up to 9 Periclimenes anthophilus Holthuis and EiblEibesfeldt, 1964 associated with Condylactis gigantea (Weinland, 1860) (Nizinski, 1989)) were not found in A. sulcata, either due to the smaller size of the snakelock anemone or to the social structure of the recorded decapod species.

The association between decapod crustaceans and sea anemones may be classed as short-term or lasting (Wirtz, 1997). Decapods that commonly occupy the column or the substratum near the base of the anemone, avoiding contact with its tentacles to avoid being stung, probably only seek protection from predators when other shelters are unavailable (Stevens and Anderson, 2000). Due to their location on A. sulcata in the field, the decapods E. occultus, E. complex cranchii, C. erythropus, M. brachydactyla, $P$. hirtellus and $P$. (N.) puber appear to display short-term association with the snakelock anemone. This hypothesis is supported by the laboratory data on shelter choice preferences, which revealed that significantly fewer specimens of these species seek A. sulcata when presented with an alternative shelter (a rock in the present work). Additionally, the work by Baeza et al. (2002) addressing the anemone dwelling crab Allopetrolisthes spinifrons (H. Milne Edwards, 1837) also supports this hypothesis, since symbiotic crabs displayed a strong preference for sea anemones over bare rocks. In the study area, it is possible that the grounds surrounding sampled $A$. sulcata (mainly bare rock with little algal growth) were just too exposed to allow proper shelter for decapod crustaceans which used the snakelock anemone as a "last resort". The presence of only juvenile $P$. (N.) puber in association with $A$. sulcata reinforces the role that the sea anemone may play in predator avoidance, since it would be just too small to protect adult specimens.

The presence of certain species in association with A. sulcata may be the result of escape responses induced by divers when approaching the anemone for sampling. This could explain the small number of $M$. brachydactyla and $P$. hirtellus specimens recorded in the present work.

In contrast to the short-term associations described earlier, field and laboratory data indicate that $P$. sagittifer and I. phalangium display lasting associations with $A$. sulcata. The association of $I$. phalangium with snakelock anemone, as well as its social structure, has been described in detail by Wirtz and Diesel (1983) and Diesel (1988). Although up to five specimens of I. phalangium can be present on a single A. sulcata, most hosts only contain one or two specimens (commonly a mated pair), as recorded in the present work. Although the social structure of $P$. sagittifer living on A. sulcata has never been addressed in detail, the occurrence of either solitary individuals or a mated pair has also been described for Periclimenes ornatus Bruce, 1969 (Omori et al., 1994). Despite this similarity, the social structure of $P$. sagittifer differs from that recorded for other Periclimenes species, since $P$. anthophilus, P. holthuisi Bruce, 1969, P. pedersoni 
Chace, 1958 and P. yucatanicus Ives, 1891 can occur in aggregations of several individuals in a single host (Limbaugh et al., 1961; Mahnken, 1972; Khan et al., 2003). Additionally, while $P$. anthophilus lacks pronounced agonistic behaviours and is morphologically poorly equipped for fighting (relatively small chelae), $P$. sagittifer, as well as other Periclimenes members of the "amethysteus group" (see Udekem d'Acoz, 1999), are highly territorial, have larger chelae and readily employ their "weapons" in agonistic encounters with conspecifics (personal observation). Sargent and Wagenbach (1975) reported the occurrence of territoriality among $P$. pedersoni, particularly during fish cleaning events. Since fish cleaning behaviour has never been recorded in any Periclimenes species of the "amethysteus group", the existence of territoriality must be related to some other aspect of $P$. sagittifer. As suggested by Knowlton (1980) for the anemonedwelling Alpheus armatus Rathbun, 1901, strong predation pressure may favour the evolution of "monogamy" (in the sense of co-existence of a heterosexual pair in the same host).

The absence of $P$. sagittifer and $I$. phalangium specimens in the area surrounding the mouth of the host anemone was not expected, since other symbiotic decapods have already been recorded in the mouth of their host anemone (e.g. P. holthuisi on Macrodactyla doreensis (Quoy and Gaimard, 1833) (Khan et al., 2003); T. amboinensis in Stichodactyla haddoni (Saville-Kent, 1893) (Khan et al., 2004)). One possible explanation for $P$. sagittifer and $I$. phalangium preferential location on the anemones' tentacles are their feeding practices, since in that area they might find trapped planktonic organisms and P. sagittifer could more easily clip and consume the host tentacles.

Species seeking shelter for brief periods on $A$. sulcata can try to monopolise this resource, particularly if they are equipped with "strong weaponry", such as well developed chelae (Thiel and Baeza, 2001). Although this assumption may be true for $M$. brachydactyla, $P$. hirtellus and $P$. (N.) puber, since they were never recorded with conspecifics or any other crab species (including I. phalangium), the small number of recorded specimens prevent us from fully supporting or refuting this hypothesis. As for those species showing short-term associations, $P$. sagittifer and I. phalangium will also certainly benefit from the protection against predation provided by their host. Additionally, when associating with snakelock anemones these species may find a conspecific of the opposing sex to mate and a food source (either prey captured by their host or parts of the anemone). Inachus phalangium is known to scrape slime and detritus from the tentacles of $A$. sulcata (Wirtz and Diesel, 1983). Periclimenes species associated with anemones are known to feed on their tentacles (Fautin et al., 1995; Khan et al., 2003). This type of feeding behaviour has also been recorded in aquaria for $P$. sagittifer (Grippa and Udekem d'Acoz, 1996). Other decapod associates of sea anemones use their host as a vantage point for suspension feeding, but do not depend on them for food (Valdivia and Stotz, 2006). According to Spotte (1996), host anemones with zooxanthellae may benefit from ammonia produced by symbiotic shrimp living among their tentacles. The presence of zooxanthellae has already been confirmed for A. sulcata (Harland et al., 1991; Roberts et al., 1999). However, it remains to be confirmed whether it truly benefits from the ammonia production of $P$. sagittifer. If this benefit is not experimentally validated, the relation between $P$. sagittifer and A. sulcata would be that of parasitism.

As predicted by the model proposed by Baeza and Thiel (2003), both P. sagittifer and I. phalangium species are more commonly present either alone or in heterosexual pairs, so they must efficiently defend their host against intruders. This host protection seems to be more pronounced in $P$. sagittifer, namely against conspecifics. Concerning interspecific intruders, $P$. sagittifer tolerated the presence of E. occultus, E. complex cranchii and $I$. phalangium in the same host. This behaviour may be associated with the fact that A. sulcata is difficult to monopolise, not due to its individual size (compared to the larger $T$. cricoides or $C$. gigantean), but to the large multi-individual patches that this species may form. Instead of displaying agonistic behaviours towards all decapod species seeking shelter in its host anemone, P. sagittifer (and probably also $I$. phalangium) concentrate their efforts against conspecifics.

Future studies should address the agonistic behaviours of $P$. sagittifer towards conspecifics and determine whether the presence of juveniles of $P$. sagittifer is tolerated in the same host occupied by an adult specimen or a breeding pair (as recorded by Omori et al. (1994) for P. ornatus). It would also be interesting to monitor the agonistic responses of a breeding pair towards a single spec- 
imen: will a male in a breeding pair display the same level of aggression towards an "invading" male as towards a female? Would a female in a breeding pair be more tolerant towards an "invading" male than a female? The occurrence of any geographical changes in decapod species composition associated with snakelock anemones in areas where larger anemones are also present (Condylactis aurantiaca (Delle Chiaje, 1825) in the Mediterranean Sea, and T. cricoides in Madeira and the Canary Islands) should also be evaluated. In addition, the association of other non-decapod crustaceans with A. sulcata, namely mysids and caprelids, should also be focused, since they were commonly seen near sampled snakelock anemones.

\section{ACKNOWLEDGEMENTS}

The authors would like to thank Fundação para a Ciência e a Tecnologia (scholarship SFRH/BPD/ 18009/2004) of the Portuguese government for their financial support. We would also like to thank Dr. Martin Thiel and an anonymous referee, who greatly improved the present work with their valuable comments.

\section{REFERENCES}

Baeza, J.A. and M. Thiel. - 2000. Host use pattern and life history of Liopetrolisthes mitra, a crab associate of the black sea urchin Tetrapygus niger. J. Mar. Biol. Ass. U.K., 80: 639-645.

Baeza, J.A, W. Stotz and M. Thiel. - 2002. Agonistic behaviour and development of territoriality during ontogeny of the sea anemone dwelling crab Allopetrolisthes spinifrons ( $\mathrm{H}$. Milne Edwards, 1837) (Decapoda: Anomura: Porcellanidae). Mar. Freshw. Behav. Physiol., 35: 189-202.

Baeza, J.A and M. Thiel. - 2003. Predicting territorial behavior in symbiotic crabs using host characteristics: a comparative study and proposal of a model. Mar. Biol., 142: 93-100.

Diesel, R. - 1988. Male-female association in the spider crab Inachus phalangium: the influence of female reproductive stage size. J. Crust. Biol., 8: 63-69.

Fautin, D.G., C.-G. Guo and J.-S. Hwang. - 1995. Costs and benefits of the symbiosis between Periclimenes brevicarpalis and its host Entacmaea quadricolor. Mar. Ecol. Prog. Ser., 129: $77-84$.

Grippa, G.B. and C. d'Udekem d'Acoz. - 1996. The genus Periclimenes Costa, 1844 in the Mediterranean Sea and the Northeastern Atlantic Ocean: review of the species and description of Periclimenes sagittifer aegylios subsp. nov. (Crustacea, Decapoda, Caridea, Pontoniinae). Atti Soc. it. Sci. nat. Museo civ. nat. Milano, 135: 401-412.

Haines, C.M., M. Edmunds and A.R. Pewsey. - 1994. The pea crab, Pinnotheres pisum (Linnaeus, 1767), and its association with the common mussel, Mytilus edulis (Linnaeus, 1758), in the Solent (UK). J. Shell. Res., 13: 5-10.
Harland, A.D., L.M. Fixter, P.S. Davies and R.A. Anderson. 1991. Distribution of lipids between the zooxanthellae and animal compartment in the symbiotic sea anemone Anemonia viridis: wax esters, triglycerides and fatty acids. Mar. Biol., 110: 13-19.

Herrkind, W., G. Stanton and E. Cocklin. - 1976. Initial characterization of the commensal complex associated with the anemone, Lebrunia danae, at Grand Bahama. Bull. Mar. Sci., 26: 65-71.

Knowlton, N. - 1980. Sexual selection and dimorphism in two demes of a symbiotic, pair-bonding snapping shrimp. Evolution, 34: 161-173.

Limbaugh, C., H. Pederson and F.A. Chace, Jr. - 1961. Shrimps that clean fishes. Bull. Mar. Sci. Gulf Carib., 11: 237-257.

Jonsson, L.G., T. Lundälv and K. Johannesson. - 2001. Symbiotic associations between anthozoans and crustaceans in a temperate coastal area. Mar. Ecol. Prog. Ser., 129: 77-84.

Khan, R.N., J.H.A. Becker, A.L. Crowther and I.D. Lawn. -2003. Sea anemone host selection by the symbiotic saddled cleaner shrimp Periclimenes holthuisi. Mar. Freshw. Res., 54: 653-656.

Khan, R.N., J.H.A. Becker, A.L. Crowther and I.D. Lawn. - 2004. Spatial distribution of symbiotic shrimps (Periclimenes holthuisi, P. bervicarpalis, Thor amboinensis) on the sea anemone Stichodactyla haddoni. J. Mar. Biol. Ass. U.K., 84: 201-203.

Mahnken, C. - 1972. Observations on cleaner shrimps of the genus Periclimenes. Bull. Nat. Hist. Mus. Los Angeles Co., 14: 71-83.

Nizinski, M.S. - 1989. Ecological distribution, demography and behavioral observations on Periclimenes anthophilus, an atypical symbiotic cleaner shrimp. Bull. Mar. Sci., 45: 174-188.

Palmer, P. - 1995. Occurrence of a New Zealand pea crab, Pinnotheres novaezelandiae, in five species of surf clam. Mar. Freshwater Res., 46: 1071-1075.

Omori, K., Y. Yanagisawa and N. Hori. - 1994. Life history of the caridean shrimp Periclimenes ornatus Bruce associated with a sea anemone in southwest Japan. J. Crust. Biol., 14: 132-145. Roberts, J.M., P.S.Davies, L.M. Fixter, L.M. and T. Preston. -
1999. Primary site and initial products of ammonium assimilation in the symbiotic sea anemone Anemonia viridis. Mar. Biol., 110: 223-236.

Ross, D.M. - 1983. Symbiotic relations. In: L.G. Abele (ed.) The Biology of Crustacea Vol. 7, pp 163-212 Academic Press, New York.

Sargent, R.C. and G.E. Wagenbach. - 1975. Cleaning behavior of the shrimp, Periclimenes anthophilus Holthius and EiblEibesfeldt (Crustacea: Decapoda: Natantia). Bull. Mar. Sci., 25: 466-472.

Spotte, S. - 1996. Supply of regenerated nitrogen to sea anemones by their symbiotic shrimp. J. Exp. Mar. Biol. Ecol., 198: 27-36.

Stevens, B.G. and P.J. Anderson. - 2000. An association between the anemone, Cribinopsis fernldi, and shrimps of the family Hippolytidae and Pandalidae. J. Northw. Atl. Fish. Sci., 27: 77-82.

Thiel, M. and J.A. Baeza. - 2001. Factors affecting the social behaviour of crustaceans living symbiotically with other marine invertebrates: a modeling approach. Symbiosis, 30: 163-190.

Udekem d'Acoz, C. d'. - 1999. Inventaire et distribution des crustacés décapodes de l'Atlantique nord oriental, de la Méditerranée et des eaux continentales adjacentes au nord de $25^{\circ}$ N. Patrimoines naturels (M.N.H.N./S.P.N.), 40: 1-383.

Valdivia, N. and W. Stotz - 2006. Feeding behavior of the porcellanid crab Allopetrolisthes spinifrons, symbiont of the sea anemone Phymactis papillosa. J. Crust. Biol. 26: 308-315.

Wirtz, P. - 1997. Crustaceans symbionts of the sea anemone Telmatactis cricoides at Madeira and Canary Islands. J. Zool. Lond., 242: 799-811.

Wirtz, P. and R. Diesel. - 1983. The social structure of Inachus phalangium, a spider crab associated with the sea anemone Anemonia sulcata. Z. Tierpsychologie, 62: 209-234.

Zar, J.H. - 1996. Biostatistical analysis. Prentice Hall, New Jersey.

Scient. ed.: P. Abelló.

Received September 26, 2006. Accepted March 6, 2007.

Publlished online May 28, 2007. 